\title{
Strategies and tools for knowledge management practices in selected academic libraries in Nigeria and South Africa
}

\begin{tabular}{|c|c|}
\hline \multicolumn{2}{|c|}{$\begin{array}{l}\text { Authors: } \\
\text { Rexwhite T. Enakrire }{ }^{1} \text { (1) } \\
\text { Omwoyo B. Onyancha }{ }^{1} \text { (I) }\end{array}$} \\
\hline \multicolumn{2}{|c|}{$\begin{array}{l}\text { Affiliations: } \\
{ }^{1} \text { Department of Information } \\
\text { Science, Faculty of Arts, } \\
\text { School of Human Sciences, } \\
\text { University of South Africa, } \\
\text { Pretoria, South Africa }\end{array}$} \\
\hline \multicolumn{2}{|c|}{$\begin{array}{l}\text { Corresponding author: } \\
\text { Rexwhite Enakrire, } \\
\text { rexwhite.enakrire80@gmail. } \\
\text { com }\end{array}$} \\
\hline \multicolumn{2}{|c|}{$\begin{array}{l}\text { Dates: } \\
\text { Received: } 02 \text { Oct. } 2019 \\
\text { Accepted: } 01 \text { Sept. } 2020 \\
\text { Published: } 18 \text { Nov. } 2020\end{array}$} \\
\hline \multicolumn{2}{|c|}{$\begin{array}{l}\text { How to cite this article: } \\
\text { Enakrire, R.T. \& } \\
\text { Onyancha, O.B., 2020, } \\
\text { 'Strategies and tools for } \\
\text { knowledge management } \\
\text { practices in selected academic } \\
\text { libraries in Nigeria and South } \\
\text { Africa', South African Journal } \\
\text { of Information Management } \\
\text { 22(1), a1159. https://doi. } \\
\text { org/10.4102/sajim.v22i1.1159 }\end{array}$} \\
\hline \multicolumn{2}{|c|}{$\begin{array}{l}\text { Copyright: } \\
\text { (c) 2020. The Authors. } \\
\text { Licensee: AOSIS. This work } \\
\text { is licensed under the } \\
\text { Creative Commons } \\
\text { Attribution License. }\end{array}$} \\
\hline \multicolumn{2}{|l|}{ Read online: } \\
\hline 口pra & $\begin{array}{l}\text { Scan this QR } \\
\text { code with your } \\
\text { smart phone or } \\
\text { mobile device } \\
\text { to read online. }\end{array}$ \\
\hline
\end{tabular}

Background: This study investigate strategies and tools for knowledge management practices (KMPs), in selected academic libraries in Nigeria and South Africa. The rationale were due to divergent library routines, increasingly users', influx of information resources in university library repository and Internet, among other factors. KMPs are touted key ingredients for library practices.

Objectives: Based on the aforementioned statement, the study investigate strategies and tools for KMPs in selected academic libraries in Nigeria and South Africa.

Methods: The quantitative research approach was based on survey, made use of questionnaire to collect data from respondents in the selected academic libraries in South Africa and Nigeria. The data collected were analysed using descriptive statistical tools.

Results: Findings indicate that, knowledge management is practiced in diverse ways to include group discussions/meetings, apprenticeships, socialisation and communities of practice, seminars, conferences and workshops. KM tools of decision support systems, database management systems, web portals, electronic document management systems (EDMS), management information systems, were used for generic and specific work operations in the library. Codification strategy serves to deepen how new knowledge promoted KM practices in academic libraries.

Conclusion: Universally KMPs is not new, though still at its infancy in some academic institutions in Africa. The need to continually share knowledge to advance quality service delivery in meeting users' information needs becomes essential. The study recommends insightful methods of coding information and knowledge as a way to re-organise and disseminate local collections, while librarians apply various KM platforms to regulate planning $\mathrm{KM}$ activities in academic libraries.

Keywords: academic libraries; knowledge management practices; knowledge management tools; Nigeria; South Africa; strategies.

\section{Introduction and problem statement}

Knowledge is an essential asset in the current information and knowledge economy (Giju et al. 2010). The extent to which an organisation and its members survive and prosper in this competitive and continuously changing digital environment depends largely on the effectiveness and efficiency with which it manages knowledge (Mostert \& Snyman 2007). Therefore, for organisations - specifically academic libraries - to grow, they must put in place mechanisms (strategies and tools) to manage knowledge, and thereby improve service delivery. After all, service delivery is why most organisations exist. The services rendered in academic libraries cannot be carried out in isolation; hence, librarians' involvement in knowledge management practices (KMPs) is important. Librarians are a key variable in this study, considering their position at institutions of higher learning. They are called upon not only to possess the right skills and competencies for managing knowledge but also to effectively apply KMPs in the operations of the library and information services they offer. Librarians are also a key variable because they are meant to share their experiences, skills and tacit knowledge with one another, whilst supporting transformation, especially as it applies to certain strategies and tools in use in their academic libraries. The operations that form part of KMPs assume different forms - from acquisition to the creation of new knowledge to the use and reuse of knowledge for diverse work operations in this environment. Librarians' knowledge and skills can therefore enhance work performance, especially in the areas of processing, managing and harvesting information and 
knowledge in a dynamic work environment. The sustainability of an organisation is dependent on the knowledge (tacit and explicit) of its employees, who use both types of knowledge to add value and become more competitive as they pursue organisational goals and gain a competitive advantage over others in their field (Smith 2001).

Wanangeye and George (2016) observe that academic libraries have evolved into learning organisations, where experiences, knowledge and skills are shared amongst colleagues on a regular basis. The reason these are called learning organisations is because different information resources are housed there, and are used to enhance the interface between learning and unlearning at the institution. Academic libraries have brought marked improvements, modifications and predictions to a variety of fields (including their own), thanks to the research carried out there. The need to share knowledge, skills and experiences amongst individuals or librarians, by meeting users' needs despite personal and/or societal problems, has compelled academic libraries to repackage their information resources. The essence of such sharing is aimed at advancing planned activities, as well as finding possible ways of executing them through machine-readable catalogues (MARC) and circulation desks, amongst others, to aid the management of knowledge (Wanangeye \& George 2016). The divergent library tasks and/or routines which librarians carry out on a daily basis, coupled with growing user needs, the influx of information in university library databases and/or repositories and the deluge of data on the internet, have imposed a great deal of change management on libraries as organisations. It has compelled librarians to deepen their research, to be able to support postgraduate students and researchers alike, in adherence of policy. This calls for the application of both strategies and tools when employing KMPs in academic libraries. Knowledge management practices encompass numerous diverse ideologies around the processes associated with knowledge management (KM) (Sirorei \& Fombad 2019), including sharing ideas amongst colleagues, life-long learning, information acquisition, KM (Khoza 2019a), knowledge transmission, academic support amongst peers and work reviews. The need for functional KMPs in academic libraries is thus critical and requires effective and efficient service delivery as part of any library's operation. Studies by Daneshgar and Parirokh (2007), Kim and Abbas (2010) and Wanangeye and George (2016) emphasise that, since academic libraries were established to support the goals of their parent institution by providing information (explicit knowledge) in different formats, librarians (acting as gatekeepers) must work collectively, as a team, to accomplish this task. The united efforts of librarians should seek to meet the information needs of diverse users through the use of sound KMPs. As librarians continue to update their knowledge, skills and competencies with the support of diverse training, the application of KM tools will help manage the information resources in academic library databases. Users' information needs can be met through a concerted effort and with the support of KM tools, even when urgent scenarios arise where librarians are given numerous tasks to complete within a short period of time (Olubunmi 2015).

Nonaka and Takeuchi (1995) investigated how corporate, commercial and business organisations use KM. Similarly, Mazorodze and Buckley (2019) note that KM enhances organisational goals, thereby delivering diverse financial benefits to companies. It would not be out of place to apply $\mathrm{KM}$ in academic libraries, considering the innovation and social networking and collaboration which Mavodza and Ngulube (2011) recommend as strategies in current academic library practices. The reason why KMPs are applied in academic libraries is that library-related operations have moved beyond meeting basic user needs to identifying procedures which can help sustain routines and improve the various niche areas of librarians' work performance. Librarians need to deepen their KMPs, since academic staff at universities rely heavily on their ability to search and retrieve information resources required for teaching, learning and research activities at those institutions. Arguably, effective KMPs will make it easier to identify the different areas of librarians' expertise or knowledge, which will in turn help lecturers with their information needs (Lin \& Dalkir 2010; Mavodza \& Ngulube 2011; White 2004). This practice involves the establishment of relationships built over time through networks and collective thinking, which avoid the pursuit of selfish interests and competition amongst colleagues and result in knowledge hoarding. When individuals hoard knowledge, any best practices associated with $\mathrm{KM}$ are minimised, and this hampers knowledge acquisition, creation, dissemination and transfer, thereby reducing organisational productivity. $\mathrm{Su}, \mathrm{Li}$ and Chow (2010) refer to knowledge sharing as a global phenomenon, though in reality certain entities still thwart its progress amongst individuals. Therefore, to advance the roles which individuals play in sustaining KMPs, the application of information technologies, organisational culture and involvement of communities of practice and the management of human capital resource need to be considered. The essence of making an individual understand these factors lies in establishing the right frame of mind, because individuals differ when it comes to the process of creating, sharing and utilising tacit and explicit knowledge for work performance in the workspace. Nonaka and Takeuchi (1995) note that as KMPs represent an array of approaches and practices, it is vital to consider the insights of individuals, along with attempts to tap, harness, share and retain those insights.

Advances in information and communication technologies (ICTs) have promoted and fostered KMPs in organisations (Rizk \& Kamel 2013). Many companies currently utilise ICTs to connect with colleagues, thereby expanding opportunities for knowledge sharing (Rizk \& Kamel 2013). The rationale for applying ICTs on knowledge-sharing platforms (such as orientation programmes for library users, teaching and learning in institutions, conferences, seminars and workshop 
environments, amongst others) is to create a transformative knowledge society. A transformative knowledge-sharing platform requires individuals to apply their personal knowledge in addressing basic life issues and other activities in the workplace, despite the evolving challenges which they increasingly face.

Ismail et al. (2013) argue that knowledge sharing is significant for organisational growth, specifically where KMPs are the variable under investigation. In reality, many people do not want to share their ideas and knowledge with others, because of a lack of trust, conflicting values or attitudinal and behavioural issues (Khoza 2019b) or their social and/or economic status (Bock \& Kim 2002; Fullwood, Rowley \& McLean 2018). Some are loath to share what they know, especially when they feel they have nothing to benefit from doing so. Organisational and individual factors thus affect knowledge sharing (Hislop 2013; Wang \& Noe 2010). The authors of this article concur that some librarians in Africa still believe that when they share what they know (tacit knowledge) it will give others the advantage, allowing others to use 'their' knowledge and experiences to advance in life and cashing in on 'their' opportunities. This perception is unusual, considering that librarians are trained to do exactly this, to be in service of others, no matter where in the world they are. Knowledge management practices demand that librarians continuously collaborate in order to better serve their users and carry out the obligations assigned to them. This form of collaboration, where academics or librarians work together as a team, serves to actualise institutional goals. No librarians should work in silos, as this approach is not sustainable in present-day libraries or workplaces. The essence of recruiting different intellectuals as librarians will help to maximise individuals' knowledge, thus building a corporate entity which is adept at helping to solve organisational problems (Ismail et al. 2013).

Kebede (2002) and Abubakar (2011) note that users' information needs are dynamic and becoming increasingly complex, demanding new skills and competencies of librarians. Users and their information needs are now more varied than ever before, as they represent different academic programmes or research bodies. Users also present novel business approaches which require unique solutions; they raise unprecedented societal problems, and many crave knowledge or guidance on creating wealth - all of this has made the task of the librarian more difficult. Admittedly, many users today are very knowledgeable about accessing information. For librarians to assist users effectively, they need to upskill themselves by acquiring more knowledge and relevant skills. Worryingly, some technological tools - which are supposed to enhance librarians' operations - have become increasingly user-unfriendly, which explains users' demand that librarians keep themselves up to date with new knowledge and competencies. Knowledge management practices would help unravel these challenges if colleagues worked together as a team, sharing their tacit knowledge and experiences, and mentoring one another in terms of best practices. This will, in turn, transform the traditional and virtual and/or technological library environment. The phobia of others 'stealing' their knowledge and possibly using it to outgrow them may explain why many are unwilling to adapt to recent changes (Singh \& Sharma 2011; Wanangeye \& George 2016), but in refusing to adapt and grow, librarians are harming themselves as well as others.

Personal psychological reasons may affect an individual's willingness to share information and may present significant obstacles (Christensen 2005). Policy plays a key role when it comes to KMPs, but the context of many libraries today especially those in Africa - does not emphasise policy implementation. It is on this premise that the present study investigates the strategies and tools for implementing KMPs in selected academic libraries in Nigeria and South Africa.

\section{Purpose of the study}

The purpose of the study on which this article is based was to determine which strategies and tools are utilised for KMPs in selected academic libraries in Nigeria and South Africa. To this end, several objectives were developed, indicating that individuals have some reluctance to sharing of knowledge:

- To examine the forms of KMPs in selected academic libraries.

- To determine which KM tools can be used to enhance related practices.

- To strategise how KMPs can be promoted in selected academic libraries.

\section{Methodology}

This research article adopted the quantitative research approach, with a survey serving as the research design. A questionnaire was used to collect data from the target population, which consisted of 300 librarians across selected academic libraries: in Nigeria, 77 librarians participated, and in South Africa, 55, bringing the total to 132. The universities sampled were located in the southern part of Nigeria, and in KwaZulu-Natal province in South Africa. The selected entities included first-generation libraries (University of Ibadan and University of KwaZulu-Natal), technological universities (Federal University of Technology in Akure and Durban University of Technology in Durban) and rural institutions (Delta State University in Abraka and the University of Zululand in Kwadlangezwa). Nigeria and South Africa were selected, as these two African countries are engaged in the education and training of librarians, with a practical involvement in quality service delivery (Enakrire 2016). The visibility of the universities' research outputs was another factor, as both countries support the funding of higher education institutions. The librarians in the academic libraries of these two countries were purposively selected based on the nature of their job specifications, which require the constant use of KM tools and strategies to advance quality service delivery. All the identified libraries accommodate the budgetary allocation of resources, facilities, services, policies and staffing. Although the initial target population of this 
study was 300 professional librarians, at the time of the study only 150 were available to complete the questionnaire. The first author of this article had to travel to each of the sampled academic libraries in Nigeria and South Africa to personally administer the questionnaire to the respondents, who were given 3 weeks to complete it. A follow-up mail was sent as a reminder, before the researcher returned to collect the completed questionnaires. Of the 150 copies distributed, only 132 were completed and returned. The retrieved questionnaires were analysed using descriptive and inferential statistics. The platform used for analysing the retrieved data, after coding, was Statistical Package of Social Sciences (SPSS) software. Next, the article presents the results of this study.

\section{Ethical consideration}

Ethical clearance was obtained from the University of Zululand and circulated to the sampled research environment, reference numbers: (UZREC 171110-30 and PGD2013/24).

\section{Results and discussion of findings Knowledge management practices in academic libraries}

In this segment, respondents were asked to state which forms of KMP are used in their respective university libraries.

The results in Table 1 indicate that diverse KMPs manifest themselves in the university libraries sampled in the two countries. The most common forms are group discussions or meetings, apprenticeships, in-house training, socialisation and communities of practice, with each having a different response rate (see Table 1). The lowest response rate $(75 \%)$ is for seminars, conferences and workshops. Variations in terms of how KM is practised at each library could be attributed to the fact that the work operations and procedures followed are intertwined. Based on the study findings, the authors of this article are of the view that library practices in respect of routines, procedures, policies, application, knowledge and

TABLE 1: Forms of knowledge management practices in academic libraries.

\begin{tabular}{lrrrrrr}
\hline KMPs & $\begin{array}{r}\text { UI } \\
(\mathbf{\%})\end{array}$ & $\begin{array}{r}\text { FUT } \\
(\mathbf{\%})\end{array}$ & $\begin{array}{r}\text { DSU } \\
(\mathbf{\%})\end{array}$ & $\begin{array}{c}\text { UZ } \\
(\mathbf{\%})\end{array}$ & $\begin{array}{c}\text { UKZN } \\
(\mathbf{\%})\end{array}$ & $\begin{array}{r}\text { DUT } \\
(\mathbf{\%})\end{array}$ \\
\hline Group discussions or meetings & 100.0 & 93.0 & 96.0 & 100.0 & 94.0 & 96.0 \\
Apprenticeships and mentoring & 98.0 & 97.0 & 98.0 & 86.0 & 92.0 & 100.0 \\
In-house training & 86.0 & 100.0 & 87.0 & 94.0 & 86.0 & 93.0 \\
Routine documentation & 88.0 & 95.0 & 93.0 & 83.0 & 95.0 & 94.0 \\
Communication network within library & 91.0 & 97.0 & 81.0 & 85.0 & 88.0 & 97.0 \\
Socialisation & 100.0 & 97.0 & 89.0 & 100.0 & 95.0 & 97.0 \\
Seminars, conferences and workshops & 88.0 & 88.0 & 87.0 & 87.0 & 75.0 & 83.0 \\
Storytelling & 93.0 & 98.0 & 95.0 & 90.0 & 95.0 & 89.0 \\
Communities of practice & 100.0 & 98.0 & 97.0 & 100.0 & 100.0 & 95.0 \\
Average \% & 93.8 & 95.9 & 91.7 & 91.7 & 91.1 & 93.8 \\
Sample sizes & 29.0 & 16.0 & 32.0 & 9.0 & 28.0 & 18.0 \\
\hline
\end{tabular}

Source: Enakrire, R.T., 2016, 'The use of information and communication technologies fo the support of knowledge management in selected academic libraries in Nigeria and South Africa', PhD thesis, University of Zululand, Kwadlangezwa, viewed 20 June 2016, from http:// Uzspace.Uzulu.Ac.Za/Handle/10530/1470

KMPs, knowledge management practices; UI, University of Ibadan; FUT, Federal University of Technology; DSU, Delta State University; UZ, University of Zululand; UKZN, University of KwaZulu-Natal; DUT, Durban University of Technology. skills are used to manage information and knowledge on a daily basis. How these factors have changed over time is the concern of the researchers. The assumption was that policy would play a key role in KMPs, resulting in present-day libraries being engrossed in knowledge reorganisation (Jain 2007; Wanangeye \& George 2016).

Wanangeye and George (2016) observe that KMPs are largely applied amongst groups of people with common interests. Groups do this in order to work together as teams (communities of practice) to learn from one another under the supervision of a master. The authors believe that in-house training, socialisation, seminars, conferences and workshops could count as other forms of KMP. As Jain (2007:389) suggests, librarians should transform themselves into value-added knowledge professionals with the capacity to visualise and strategise around rapid changes. Such changes require instantaneous communications that could transform organisations from paper-based entities to thriving networked relationships. Singh and Sharma (2011) argue that an organisation's culture changes the work performance and techniques of its employees - in this instance, librarians. The techniques could help librarians analyse a certain framework of knowledge-creation platforms. Knowledgecreation platforms require users to use different methods and techniques to develop systems thinking of strategies and management practices (Liao 2003:156). The authors of this article believe that, when all librarians apply the same KMP principles, policies and standards, those practices which revolve around the routine of acquiring new knowledge will be deepened and sustained, and that will enable practitioners to achieve optimal service delivery. Knowledge management practices are improved when theoretical, methodological and scientific approaches are adopted. The achievement of organisational growth is based on an understanding of the management style which applies in the organisation. This makes the community of practice so important, because if the management style is not well understood, there is no way in which people can work together as a team. Even by sharing work experiences, it gives them an opportunity to create, acquire, organise, store and share or disseminate new knowledge, for subsequent reuse as they put into practise KM approaches in their own academic libraries.

\section{Tools for knowledge management practices in academic libraries}

In this segment, respondents were asked to indicate which tools could be used to enhance KMPs in their various academic libraries.

The results in Table 2 reveal that word processors, search engines and information retrieval tools are crucial and commonly used tools for KMPs in the sampled academic libraries. Noticeably, database management systems $(88 \%)$, web portals $(83 \%)$, electronic document management system (EDMS) (81\%), management information systems $(81 \%)$ and barcode readers $(89 \%)$ were the primary $\mathrm{KM}$ 
TABLE 2: Tools for knowledge management practices in academic libraries.

\begin{tabular}{|c|c|c|c|c|c|c|}
\hline Tools & $\begin{array}{c}\text { UI } \\
(\%)\end{array}$ & $\begin{array}{l}\text { FUT } \\
(\%)\end{array}$ & $\begin{array}{l}\text { DSU } \\
(\%)\end{array}$ & $\begin{array}{c}\text { UZ } \\
(\%)\end{array}$ & $\begin{array}{c}\text { UKZN } \\
(\%)\end{array}$ & $\begin{array}{l}\text { DUT } \\
(\%)\end{array}$ \\
\hline Decision support systems & 66.0 & 25.0 & 31.0 & 33.0 & 32.0 & 32.0 \\
\hline Word processors & 90.0 & 94.0 & 81.0 & 89.0 & 100.0 & 100.0 \\
\hline Search engines & 90.0 & 88.0 & 81.0 & 89.0 & 100.0 & 94.0 \\
\hline Semantic web & 59.0 & 56.0 & 38.0 & 78.0 & 61.0 & 78.0 \\
\hline Artificial intelligence tools & 48.0 & 31.0 & 22.0 & 33.0 & 32.0 & 67.0 \\
\hline Simulation tools & 55.0 & 19.0 & 16.0 & 33.0 & 29.0 & 50.0 \\
\hline Data mining & 69.0 & 13.0 & 22.0 & 44.0 & 43.0 & 61.0 \\
\hline Information retrieval tools & 83.0 & 88.0 & 63.0 & 78.0 & 96.0 & 94.0 \\
\hline Electronic data management systems & 72.0 & 81.0 & 47.0 & 89.0 & 68.0 & 72.0 \\
\hline Database management systems & 79.0 & 88.0 & 47.0 & 89.0 & 86.0 & 78.0 \\
\hline Data warehousing & 69.0 & 50.0 & 34.0 & 78.0 & 57.0 & 56.0 \\
\hline Content management systems & 62.0 & 44.0 & 31.0 & 67.0 & 57.0 & 67.0 \\
\hline Management information systems & 79.0 & 81.0 & 50.0 & 89.0 & 75.0 & 78.0 \\
\hline Web portals & 83.0 & 88.0 & 53.0 & 56.0 & 86.0 & 89.0 \\
\hline Site maps & 69.0 & 56.0 & 31.0 & 67.0 & 64.0 & 83.0 \\
\hline Barcode readers & 69.0 & 31.0 & 59.0 & 89.0 & 82.0 & 89.0 \\
\hline Indexing and abstracting & 79.0 & 75.0 & 69.0 & 67.0 & 86.0 & 89.0 \\
\hline Average \% & 71.8 & 59.3 & 46.0 & 68.7 & 67.9 & 76.5 \\
\hline Sample sizes & 29.0 & 16.0 & 32.0 & 9.0 & 28.0 & 18.0 \\
\hline
\end{tabular}

Source: Enakrire, R.T., 2016, 'The use of information and communication technologies for the support of knowledge management in selected academic libraries in Nigeria and South support of knowledge management in selected academic libraries in Nigeria and South Africa', PhD thesis, University of Zululand,
Uzspace.Uzulu.Ac.Za/Handle/10530/1470

UI, University of Ibadan; FUT, Federal University of Technology; DSU, Delta State University; UZ, University of Zululand; UKZN, University of KwaZulu-Natal; DUT, Durban University of Technology

tools in use across the sampled libraries. The findings further revealed that the identified tools differ from one institution/library to the next, and are used for both specific and generic work operations. One reason for using these tools is to move from a traditional to a virtual workplace environment, where information and knowledge are easily available and accessible. It is one thing to have the right tools and use it to suit specific job descriptions. The authors of this article envisage that funding will be a major factor in respect of the availability of the identified tools. This study also revealed that newer technologies (artificial intelligence, robotics, nanotechnology, smart boards, tablets, iPhones and Windows 10) are now being used to facilitate KM at university libraries (Enakrire 2016). This finding corroborates that Laleye (2015:399), who found that certain $\mathrm{KM}$ tools, such as data mining, online analytical processing (OLAP), document management systems and retrieval systems, are used for specific work operations and for educational training. Knowledge management tools are believed to improve, modify and predict learning environments, where users can harvest documents and literature from different search engines - that means information is more readily accessible. On the same note, Muhammad et al. (2014:27) refer to such tools as business intelligence operation tools, which enhance the use of tactical, strategic and operational decision-making within organisations. These tools are associated with data warehousing and mining, extraction transformation loads (ETL) and OLAP, presently used in most libraries in the developed world. The authors of this article are of the view that using these tools will help to align library and information services to business-oriented services, wherever effective and efficient library operations are required. Notably, mastery of these tools requires the basic knowledge
TABLE 3: Strategies for knowledge management practices in academic libraries.

\begin{tabular}{|c|c|c|c|c|c|c|}
\hline Strategies & $\begin{array}{l}\text { UI } \\
(\%)\end{array}$ & $\begin{array}{l}\text { FUT } \\
(\%)\end{array}$ & $\begin{array}{l}\text { DSU } \\
(\%)\end{array}$ & $\begin{array}{l}\text { UZ } \\
(\%)\end{array}$ & $\begin{array}{l}\text { UKZN } \\
(\%)\end{array}$ & $\begin{array}{l}\text { DUT } \\
(\%)\end{array}$ \\
\hline $\begin{array}{l}\text { Reuse of knowledge through codification } \\
\text { strategy }\end{array}$ & 100.0 & 88.0 & 92.0 & 100.0 & 90.0 & 97.0 \\
\hline Creating value for users & 95.0 & 100.0 & 87.0 & 100.0 & 92.0 & 89.0 \\
\hline Creating coherence amongst colleagues & 96.0 & 93.0 & 96.0 & 88.0 & 97.0 & 95.0 \\
\hline $\begin{array}{l}\text { Deepening research and learning } \\
\text { processes }\end{array}$ & 100.0 & 91.0 & 91.0 & 88.0 & 95.0 & 100.0 \\
\hline $\begin{array}{l}\text { Application of skills to build new } \\
\text { knowledge }\end{array}$ & 95.0 & 93.0 & 90.0 & 88.0 & 92.0 & 91.0 \\
\hline Scaling innovation & 93.0 & 81.0 & 81.0 & 77.0 & 89.0 & 82.0 \\
\hline $\begin{array}{l}\text { Engagement with senior colleagues on } \\
\text { critical discourse }\end{array}$ & 89.0 & 86.0 & 83.0 & 88.0 & 92.0 & 93.0 \\
\hline Supporting existing structure & 88.0 & 100.0 & 90.0 & 100.0 & 92.0 & 88.0 \\
\hline Competencies and culture of the library & 89.0 & 89.0 & 80.0 & 92.0 & 80.0 & 79.0 \\
\hline Knowledge audit on quarterly basis & 89.0 & 87.0 & 86.0 & 100.0 & 85.0 & 85.0 \\
\hline Creating and sustaining knowledge bank & 93.0 & 100.0 & 86.0 & 100.0 & 88.0 & 86.0 \\
\hline Facilitating interrelated committee work & 100.0 & 98.0 & 88.0 & 100.0 & 93.0 & 90.0 \\
\hline Training and retraining of staff & 85.0 & 93.0 & 90.0 & 88.0 & 89.0 & 88.0 \\
\hline Community development projects & 88.0 & 96.0 & 91.0 & 100.0 & 93.0 & 88.0 \\
\hline $\begin{array}{l}\text { Deepening research articles, books and } \\
\text { monographs }\end{array}$ & 89.0 & 86.0 & 89.0 & 88.0 & 95.0 & 85.0 \\
\hline $\begin{array}{l}\text { Monitoring and support through } \\
\text { corporate governance }\end{array}$ & 85.0 & 93.0 & 96.0 & 100.0 & 96.0 & 85.0 \\
\hline Maintaining policy for decision-making & 88.0 & 100.0 & 90.0 & 100.0 & 92.0 & 88.0 \\
\hline $\begin{array}{l}\text { Provision of efficient and effective KM } \\
\text { entities }\end{array}$ & 95.0 & 91.0 & 91.0 & 88.0 & 95.0 & 100.0 \\
\hline $\begin{array}{l}\text { Universal access to information and } \\
\text { knowledge }\end{array}$ & 92.0 & 87.0 & 87.0 & 89.0 & 72.0 & 91.0 \\
\hline Managing people's intellect & 89.0 & 87.0 & 86.0 & 100.0 & 100.0 & 85.0 \\
\hline $\begin{array}{l}\text { Ensuring that ICT facilities are available } \\
\text { and accessible }\end{array}$ & 95.0 & 86.0 & 82.0 & 100.0 & 100.0 & 85.0 \\
\hline $\begin{array}{l}\text { Intensive face-to-face communication } \\
\text { amongst colleagues }\end{array}$ & 95.0 & 86.0 & 86.0 & 82.0 & 95.0 & 90.0 \\
\hline Average $\%$ & 95.0 & 86.0 & 86.0 & 82.0 & 95.0 & 90.0 \\
\hline Sample sizes & 29.0 & 16.0 & 32.0 & 9.0 & 28.0 & 18.0 \\
\hline
\end{tabular}

Source: Enakrire, R.T., 2016, 'The use of information and communication technologies for the support of knowledge management in selected academic libraries in Nigeria and South Africa', $\mathrm{PhD}$ thesis, University of Zululand, Kwadlangezwa, viewed 20 June 2016, from http://Uzspace. Uzulu.Ac.Za/Handle/10530/1470

UI, University of Ibadan; FUT, Federal University of Technology; DSU, Delta State University; UZ, University of Zululand; UKZN, University of KwaZulu-Natal; DUT, Durban University of Technology $\mathrm{ICT}$, information and communication technologies; KM, Knowledge management.

of their application, which means librarians will need to equip themselves with the necessary training and exposure. For example, using MARC in cataloguing and classification processes is still a novelty for some African librarians. Therefore, to make use of such tools when managing knowledge, they need to increase their tacit knowledge, and acquire specific skills (coding, building taxonomies, organisational skills, analytical and personal skills), so that they will not struggle to use them in rendering library services and fulfilling other parts of their job descriptions.

\section{Strategies for knowledge management practices in academic libraries}

This section sought to establish and recommend strategies that could promote KMPs in selected academic libraries in Nigeria and South Africa. The results are presented in Table 3.

The results reflected in Table 3 indicate that different strategies were identified to support the promotion of KMPs in academic libraries. These cut across reusing knowledge through codification strategies, deepening research and learning processes, maintaining policy for decision-making, 
providing efficient and effective $\mathrm{KM}$ entities, managing people's intellect and ensuring that ICT facilities are available/accessible to meet user/staff needs. Intensive face-to-face communication amongst colleagues was also identified as playing a role. Importantly, these strategies could work better, depending on the nature of the KMPs which librarians adopt at their respective universities. The identified strategies offer a broad spectrum of support, in terms of codifying and personalising librarians' tacit knowledge, to underpin the explicit knowledge which they already use to manage organisational activities at their libraries. The manner in which an organisation operates depends largely on the calibre of its intellectuals, their willingness to change their mind-sets, the organisational culture and their willingness to share their knowledge in transforming and ensuring conformity to the standards of the global world. The results in Table 3 show that different strategies apply to different contexts, as regards librarians' jobs specifications. For example, the reuse of knowledge through codification strategies delivered different results for UI (100\%), FUT (88\%), DSU (92\%), UZ (100\%), UKZN (90\%) and DUT (97\%), respectively. This implies that, when comparing the strategies across the two countries, entities in South Africa appear to promote KMPs more than those in Nigeria. The authors of this article believe that the strategies used for KMPs could influence the organisational culture and management support systems, because librarians use shared knowledge to access and retrieve information, whenever they render services to users (Olubunmi 2015). Some strategies have been shown to work much better when the right calibre of trained, qualified, experienced, skilled and dedicated teams is ready to foster innovation and growth in an organisation (Enakrire 2016). Studies by Hovland (2003) and Fombad (2018:198) emphasise that KM strategies are crucial in organisations, as they help to convert information and data to newer knowledge, which serves to invigorate the organisational objectives. On a similar note, Fombad (2018:198) reiterates that codification and personalisation are key factors of any strategies aimed at managing knowledge in present-day organisations. People, processes and technologies are enablers of such achievements (Fombad 2018:198). When such enablers are in place, knowledge sharing and transfer is actualised, thereby assisting librarians in rendering quality services to users (Fombad 2018:198).

The authors of this article suggest that the creation of new ideas amongst colleagues could enhance librarians' functioning, given that the sharing of knowledge or ideas is not common in African settings (mainly because of multiculturalism, and librarians' ethnicity, age, gender and cultural backgrounds) (Dube \& Ngulube 2012). Knowledge management strategies could support librarians in their daily service delivery, where - as a team - they use the available and accessible ICT facilities to manage the influx of information (e.g. research outputs in the form of theses, dissertations, term papers or monographs, deposited in an institutional repository of the university). It is expected that the outcome of using these strategies will affect the rules or policies used in knowledge production, as well as the quality of knowledge-based interventions. Therefore, the knowledge acquired from university library services will have to be incorporated in several steps, including the capturing and rebuilding of colleagues' organisational performance. In this regard, Allen (2012) argues that such a process will be achieved by strengthening KMPs amongst librarians. The authors of this article recommend that, for KMPs to be affirmed in academic libraries, the application of processes, along with technologies and people, must become even more important. This will help to move the principles of planning to concrete decision-making. It will influence the strategic support which proactive team members could offer if they work together in application of KMPs in the organisation. University libraries could therefore achieve KMP goals through collaboration and trust, which come from building a shared understanding as well as communities of practice.

\section{Conclusion and recommendations}

Academic libraries have, in recent times, been burdened with numerous responsibilities, as they meet users' information needs and, at the same time, support institutional goals. These responsibilities have overburdened many librarians, who have a lot to deal with as they face serious time constraints, despite this being the digital age. The possible ways in which to manage the growing daily influx of knowledge, and the increasingly complex demands of users, require librarians to apply certain KMP strategies and tools to optimise the support services they render their users. This scenario emphasises the need for continuous learning, where academic librarians gain more knowledge along with the skills required to optimise their use of $\mathrm{KM}$ tools. This undertaking can be strengthened if librarians continue to share their knowledge, experiences and skills, to improve on current best practices. Certain strategies, such as engaging with senior colleagues through critical discourse, intensive face-to-face communication and knowledge audits and where they are guided by policy when making decisions, amongst others, will deepen research approaches and the related activities of library practices. Currently, unequal forms of KMP are supported by certain tools in academic libraries. Some librarians - from what the authors gleaned in the course of their study - do not share their personal tacit knowledge, experiences, skills and insights when meeting users' information needs or streamlining library work operations. Ideally, if librarians could come together as one, to share what they know best, service delivery and other library-related work operations would unfold more smoothly. The ideal scenario calls for a transformation of KMPs.

It is evident from the sources of information and knowledge contained in this study that librarians need to harness and share information that could improve their work and bring growth to the library, through the KMPs discussed here. The attainment of such KMPs would efficiently strengthen the work performance of librarians at different levels in their work environment, across countries. The researchers thus conclude that KMPs play a significant role in academic libraries, both in 
Nigeria and South Africa. Through institutional support, policies and diverse $\mathrm{KM}$ tools, the application of specific practices in academic libraries can be deepened. Different tools aimed at managing knowledge support various methods of coding, organising and disseminating local collections across different library platforms. The methods of coding, organising and disseminating local collections can be revitalised through proper planning and the execution of a KMP learning interface.

The authors' findings corroborate the notion that certain strategies and tools (see Tables 2 and 3) are not used in a uniform manner, but are used and reused in alternative ways. Examples are codification strategies aimed at deepening research and learning processes, support for the existing structure, competencies and culture of the library, the training and re-training of staff and ensuring that ICT facilities are available and accessible to meet the needs of individuals and organisations. Word processors, search engines, database management systems, management information systems and information retrieval tools were identified as most significant for putting into practice the KM efforts at the sampled academic libraries under study. The authors emphasise that this might be the case in most academic libraries across the world, but in Africa, taking similar strides to adopt KMPs would certainly improve the services they offer. Consortia have brought many academic libraries together to train librarians in a variety of skills, including how to integrate KMPs in their services. Based on the findings of this study, the authors recommend the continued promotion of KMPs in academic libraries to bring about the benefits of harnessing and sharing what is known so that others can also gain expertise. This will deepen the educational programmes, research support and community services which librarians offer their users. The study further advocates the use of more recent $\mathrm{KM}$ tools, such as data warehouses, search engines, semantic webs, artificial intelligence tools, simulation tools and data mining, amongst others. There is also a need to embrace strategic ways of adhering to best practices, as put forward by KM-related consortia, and to collaborate on this with other libraries. The study further recommends using insightful methods of coding information and knowledge as a way of reorganising and disseminating local collections, even as academic librarians employ various platforms to regulate their planning of KM activities.

\section{Acknowledgements}

The authors would like to acknowledge the librarians at the University of Ibadan, University of KwaZulu-Natal, Federal University of Technology Akure, Durban University of Technology Durban, Delta State University, Abraka and University of Zululand, Kwadlangezwa both in Nigeria and South Africa for responding to the questionnaire administered to them for data collection towards this research investigation.

\section{Competing interests}

There is no conflicting interest towards this research article.

\section{Authors' contributions}

The article titled was both conceptualised, written, edited and harmonised by both the authors.

\section{Funding information}

There was no funding till the time this article was written. However, the University of South Africa, being the employer of both authors will be providing the publication fees for this research article.

\section{Data availability statement}

Data for this study are available and can be shared when required or necessary upon reasonable request to the corresponding author.

\section{Disclaimer}

The views and opinions regarding this research article are those of both the authors and do not necessarily reflect the official policy or position of any affiliated agency of the authors.

\section{References}

Abubakar, B.M., 2011, 'Academic libraries in Nigeria in the 21st century', Library Philosophy and Practice (e-journal) 446, 1-5, viewed 02 June 2017, from http:// digitalcommons.unl.edu/libphilprac/446.

Allen, A., 2012, KM Australia Congress, 2012: An interview with Felicity McNish, viewed 22 May 2013, from http://knowledgebird.com/km-australia-congress2012-interview-felicity-mcnish-woods-bagot/.

Bock, G.W. \& Kim, Y.G., 2002, 'Breaking the myths of rewards: An exploratory study of attitudes about knowledge sharing', Information Resources Management Journal 15(2), 14-21. https://doi.org/10.4018/irmj.2002040102

Christensen, P.H., 2005, Facilitating knowledge sharing: A conceptual framework, viewed 22 August 2018, from http://uk.cbs.dk/content/download/33323/466533/ file/SMG\%20WP\%204-2005.pdf.

Daneshgar, F. \& Parirokh, M., 2007, 'A knowledge schema for organisational learning in academic libraries', Knowledge Management Research and Practice 5(1), 22-33. https://doi.org/10.1057/palgrave.kmrp.8500127

Dube, L. \& Ngulube, P., 2012, 'Knowledge sharing in a multicultural environment: Challenges and opportunities', South African Journal of Libraries and Information Science 78(1), 68-77. https://doi.org/10.7553/78-1-48

Enakrire, R.T., 2016, 'The use of information and communication technologies for the support of knowledge management in selected academic libraries in Nigeria and South Africa', PhD thesis, University of Zululand, Kwadlangezwa, viewed 20 June 2016, from http://Uzspace.Uzulu.Ac.Za/Handle/10530/1470.

Fombad, M., 2018, 'Knowledge management for poverty eradication: A South African perspective', Journal of Information Communication and Ethics in Society 16(2), 193-213. https://doi.org/10.1108/JICES-04-2017-0022

Fullwood, R., Rowley, J. \& McLean, J., 2018, 'Exploring the factors that influence knowledge sharing between academics', Journal of Further and Higher Education 43(8), 1051-1063. https://doi.org/10.1080/0309877X.2018.1448928

Giju, G.C., Badea, L., Ruiz, V.R.L. \& Peña, D.N., 2010, 'Knowledge management - The key resource in the knowledge economy', Theoretical and Applied Economics 6(547), 27-36

Hislop, D., 2013, Knowledge management in organizations, Oxford University Press, Oxford.

Hovland, I., 2003, Knowledge management and organisational learning: An international development perspective, viewed 20 August 2018, from https://pdfs.semanticscholar.org/c650/491d19df1fc30198b418d2f117349056 86 ca.pdf.

Ismail, I.M., Kulkarni, A.G., Kamble, S.V., Borker, S.A., Rekha, R. \& Amruth, M., 2013, 'Knowledge, attitude and practice about bio-medical waste management among personal of a tertiary health institute in Dakshina Kannada, Karnataka', AlAmeen Journal of Medical Science 6(4), 376-380.

Jain, P., 2007, 'An empirical study of knowledge management in academic libraries in East and Southern Africa', Library Review 56(5), 377-392. https://doi.org/10.1108/ 00242530710750572

Kebede, G., 2002, 'The changing information needs of users in electronic information environments', The Electronic Library 20(1), 14-21. https://doi.org/10.1108/ 02640470210418227 
Khoza, L.T., 2019a, 'Measuring knowledge sharing behaviour among software development teams', South African Journal of Information Management 21(1) a1076. https://doi.org/10.4102/sajim.v21i1.1076

Khoza, L.T., 2019b, 'Managing knowledge leakage during knowledge sharing in software development organisations', South African Journal of Information Management 21(1), a1075. https://doi.org/10.4102/sajim.v21i1.1075

Kim, Y. \& Abbas, J., 2010, 'Adoption of Library 2.0 functionalities by academic libraries and users: A knowledge management perspective', Journal of Academic Librarianship 36(3), 211-218. https://doi.org/10.1016/j.acalib.2010.03.003

Laleye, A.M., 2015, 'Educational technology for effective service delivery in educational training and research in Nigeria', Procedia-Social and Behavioural Sciences 176, 398-404. https://doi.org/10.1016/j.sbspro.2015.01.488

Liao, S.H., 2003, 'Knowledge management technologies and applications - Literature review from 1995 to 2002', Expert Systems with Applications 25(2), 155-164. https://doi.org/10.1016/S0957-4174(03)00043-5

Lin, Y. \& Dalkir, K., 2010, 'Factors affecting KM implementation in the Chinese community', International Journal of Knowledge Management 6(1), 1-22. https:// doi.org/10.4018/jkm.2010103001

Mavodza, J. \& Ngulube, P., 2011, 'Exploring the use of knowledge management practices in an academic library in a changing information environment', South African Journal of Libraries \& Information Science 77(1), 15-25. https://doi. org/10.7553/77-1-63

Mazorodze, A.H. \& Buckley, S., 2019, 'Knowledge management in knowledgeintensive organisations: Understanding its benefits, processes, infrastructure and barriers', South African Journal of Information Management 21(1), a990. https:// doi.org/10.4102/sajim.v21i1.990

Mostert, J.C. \& Snyman, M.M.M., 2007, 'Knowledge management framework for the development of an effective knowledge management strategy', South Africa Journal of Information Management 9(2), a25. https://doi.org/10.4102/sajim.v9i2.25

Muhammad, G., Ibrahim, J., Bhatti, Z. \& Waqas, A., 2014, 'Business intelligence as a knowledge management tool in providing financial consultancy services', American Journal of Information Systems 2(2), 26-32, viewed 03 April 2015, from http://pubs.sciepub.com/ajis/2/2/1.
Nonaka, I. \& Takeuchi, H., 1995, The knowledge-creating company: How Japanese companies create the dynamics of innovation, Oxford University Press, New York, NY.

Olubunmi, O.F., 2015, 'Knowledge management as an important tool in organisational management: A review of literature', Library Philosophy and Practice (e-journal) 1238, viewed 05 June 2020, from http://digitalcommons.unl.edu/libphilprac/ 1238 .

Rizk, N. \& Kamel, S., 2013, 'ICT and building a knowledge based society in Egypt', International Journal of Knowledge Management 9(1), 1-20. https://doi. org/10.4018/jkm.2013010101

Singh, A.K. \& Sharma, V., 2011, 'Knowledge management antecedents and its impact on employee satisfaction: A study on Indian telecommunication industries', Learning Organization 18(2), 115-130. https://doi.org/10.1108/09696471111103722

Sirorei, E.C. \& Fombad, M.C., 2019, 'Knowledge management processes at St Paul's University Library in Kenya', South African Journal of Information Management 21(1), a946. https://doi.org/10.4102/sajim.v21i1.946

Smith, E.A., 2001, 'The role of tacit and explicit knowledge in the workplace', Journal of Knowledge Management 5(4), 311-321. https://doi.org/10.1108/13673270110 411733

Su, W.B., Li, X. \& Chow, C.W., 2010, 'Exploring the extent and impediments of knowledge sharing in Chinese business enterprise', International Journal of Knowledge Management 6(4), 24-46. https://doi.org/10.4018/jkm.2010100102

Wanangeye, W.L. \& George, B.O., 2016, 'Knowledge management practices and performance of academic libraries: A case of Mount Kenya University, Kigali Campus Library', World Journal of Computer Application and Technology 4(2), 34-39. https://doi.org/10.13189/wjcat.2016.040202

Wang, S. \& Noe, R.A., 2010, 'Knowledge sharing: A review and directions for future research', Human Resource Management Review 20(2), 115-131. https://doi. org/10.1016/j.hrmr.2009.10.001

White, T., 2004, 'Knowledge management in an academic library, based on the case study "KM within OULS"', paper presented at the 70th IFLA General Conference
and Council, Buenos Aires, viewed 20 July 2018, from http://www.ifla.org/IV/ ifla70/papers/089e-White.pdf. 